Zeszyty Naukowe Szkoły Głównej Gospodarstwa Wiejskiego w Warszawie Problemy Rolnictwa Światowego tom 17 (XXXII), zeszyt 1, 2017: 31-42

DOI: $10.22630 /$ PRS.2017.17.1.3

Andrzej Czyżewski ${ }^{1}$, Jakub Staniszewski ${ }^{2}$

Uniwersytet Ekonomiczny w Poznaniu

\title{
Wydajność pracy jako przesłanka restrukturyzacji zatrudnienia w rolnictwie
}

\section{Labor Productivity as a Premise to Restructure Employment in Agriculture}

\begin{abstract}
Synopsis. Poprawę wydajności pracy w rolnictwie można osiągnąć m.in. poprzez zmianę struktury (restrukturyzację) zatrudnienia, polegającą na zwiększaniu udziału typów produkcyjnych, gdzie czynnik jest wydajniej wykorzystywany. Dla poparcia tej tezy dokonano dekompozycji wzrostu wydajności pracy w rolnictwie krajów UE, w latach 2005-2013, z zastosowaniem metody shift-share. Wyniki badań wskazują, że większą dynamiką struktury zatrudnienia cechowały się nowe kraje członkowskie. Zmiany polegały głównie na spadku znaczenia produkcji mieszanej na rzecz upraw polowych. W krajach takich jak Litwa, Bułgaria, Cypr i Łotwa na znaczeniu zyskiwały typy produkcji o ponadprzeciętnej wydajności pracy. Ponadto na Łotwie i w Danii większe znaczenie w wykorzystaniu czynnika pracy zyskiwały typy gospodarstw cechujące się ponadprzeciętnym przyrostem wydajności pracy. Częstsze były jednak zmiany zachodzące w kierunku odwrotnym.
\end{abstract}

Slowa kluczowe: zmiana strukturalna, rolnictwo, shift-share, restrukturyzacja, Unia Europejska

\begin{abstract}
Improvement in agricultural labour productivity can be achieved, among others, by the change in the employment structure, based on increase in the share of types of farming, where labour productivity is higher. To support this thesis, decomposition of labour productivity growth in the agriculture sector of EU countries, in years 2005-2013 has been carried out, using the shift-share method. Research results shows that the new Member States are more dynamic in this respect. The changes mainly meant a switch from a mixed production to a field cropping. In countries such as Lithuania, Bulgaria, Cyprus and Latvia, the production in the farming types of above-average productivity was increasing. In Latvia and Denmark, the share of employment in sectors with higher productivity growth was increasing. However, changes in the opposite direction were more common.
\end{abstract}

Key words: structural change, agriculture, shift-share, restructuring, European Union

\section{Wprowadzenie}

Niniejszy artykuł wpisuje się $\mathrm{w}$ nurt badań nad naturą zmian strukturalnych zachodzących w sektorze rolnym, w szczególności zmian w rozkładzie czynnika pracy i wpływu tych zmian na wydajność pracy. Celem badania jest określenie czy zmiany strukturalne zachodzące $\mathrm{w}$ rozkładzie czynnika pracy $\mathrm{w}$ rolnictwie $\mathrm{w}$ krajach Unii Europejskiej w latach 2005-2013, przyczyniały się do poprawy ogólnej wydajności pracy w sektorze. To znaczy, czy zwiększał się udział w wykorzystaniu czynnika pracy w typach gospodarstw, które charakteryzowały się wysoką wydajnością pracy oraz wysoką dynamiką

${ }^{1}$ prof. zw. dr hab., Katedra Makroekonomii i Gospodarki Żywnościowej UE w Poznaniu, Al. Niepodległości 10, 61-875 Poznań, e-mail: kmigz@ue.poznan.pl

${ }^{2}$ mgr, Katedra Makroekonomii i Gospodarki Żywnościowej UE w Poznaniu, Al. Niepodległości 10,

61-875 Poznań, e-mail: jakub.staniszewski@ue.poznan.pl 
tej wydajności. Analiza porównawcza przeprowadzona została za pomocą metody shiftshare. Porównany został postęp jaki dokonał się w tej materii w rolnictwie krajów UE-27, ze szczególnym uwzględnieniem nowych krajów członkowskich z obszaru Europy środkowo-wschodniej (CEE: Czechy, Słowacja, Polska, Węgry, Słowenia, Litwa, Łotwa, Estonia, Bułgaria, Rumunia). Przystąpienie tych krajów do UE i związane z tym korzyści w postaci pełnego dostępu do wspólnego rynku oraz wsparcia środkami wspólnej polityki rolnej (WPR) stanowiły swoisty „szok”, indukujący zmiany strukturalne. Stąd też spodziewać się można, że w wymienionych krajach będą one przebiegały intensywniej, niż w krajach UE-15. Badania pozwolą ustalić, który rodzaj rolniczej specjalizacji w największym stopniu przyczynił się do poprawy ogólnej wydajności pracy oraz czy zachodzące zmiany strukturalne wspierały ten postęp. Uzyskane wyniki stanowić mogą cenną rekomendację dla polityki restrukturyzacji zatrudnienia w sektorze rolnym, szczególnie wśród nowych krajów członkowskich, które wciąż stoją przed wyzwaniem zwiększania wydajności pracy w rolnictwie.

\section{Przegląd literatury}

Kompleksowy przegląd teoretycznych aspektów przeobrażeń strukturalnych w rolnictwie zawiera raport opracowany na potrzeby projektu SCARLED (Conceptual..., 2007). Zgodnie z tym opracowaniem zjawisko to charakteryzuje się ciagłymi zmianami w wykorzystaniu czynników pracy, kapitału i ziemi, zaś jego konsekwencję stanowią zmiany w strukturze produkcji (Conceptual..., 2007, s. I). Ponadto wymiary zmian strukturalnych mogą być postrzegane $\mathrm{z}$ różnych perspektyw (Conceptual..., 2007, s. 6). Boehlje (1999) wskazuje takie jak: rozmiar (ekonomiczny lub fizyczny) gospodarstw, dystrybucja czynników wytwórczych, sytuacja finansowa, własność, technologia lub powiąania instytucjonalne (kontraktacja, pozioma i pionowa integracja). Zegar (2009) wyróżnia strukturę agrarna, ekonomiczną, skali (koncentracja i specjalizacja), rynkową, ekologiczna, społeczno-ekonomiczna, przestrzenną oraz strukturę typu gospodarstw rolnych. Niniejsze opracowanie łączy trzy z wyżej wymienionych wymiarów - wyniki ekonomiczne, dystrybucję czynnika pracy i typ gospodarstw.

Opracowania dotyczące tego tematu można również usystematyzować ze względu na rolę, jaką przyjmują w nich zmiany strukturalne. Jak zauważa Schmitt (1990, s. 470), rozpatrywana są one zarówno jako skutek wzrostu gospodarczego, jak i jego źródło. W przypadku rolnictwa mówić możemy natomiast o badaniach konsekwencji i przyczyn zmiany strukturalnej. Przeglądu obydwu tych kategorii dokonują Vandermeulen i in. (2010, s. 4). Wśród tych pierwszych wskazują oni m.in. zmianę produktywności i efektywności rolnictwa (Vandermeulen i in., 2010, s. 7). Problem ten rozważa również niniejsze opracowanie. Jak zauważa Kuznets (1979) źródło wzrostu gospodarczego stanowić może przenoszenie zasobów do gałęzi produkcji cechujących się wyższą wydajnością. W artykule zweryfikowana zostaje adekwatność tej tezy w odniesieniu do struktury sektora rolnego krajów UE.

Wśród opracowań empirycznych podobne badania podejmuje zespół Węgierskiego Instytutu Ekonomii Rolnej - AKI (Research for..., 2016). W kompleksowy sposób przedstawia na podstawie danych Eurostat, zmiany strukturalne w rolnictwie nowych krajów członkowskich UE oraz wskazuje ich potencjalne determinanty. Opisane zostały również zmiany w specjalizacji gospodarstw (Research for..., 2016, s. 108-113) oraz 
produktywności rolnictwa (Research for..., 2016, s. 119-120). Jednak problem zależności tych dwóch zjawisk poruszony jest jedynie w sposób deskryptywny. Opracowanie Zegara (2009) prezentuje struktury gospodarstw rodzinnych w Polsce w ujęciu wielowymiarowym, uwzględniając również strukturę skali (specjalizację) oraz dynamikę tych struktur. W opracowaniu tym nie został jednak poruszony temat związków dynamiki struktur z wydajnością pracy. Z kolei Błażejczyk-Majka i Kala (2015) porównują zmiany wydajności pracy w rolnictwie „nowych” i ,starych” krajów członkowskich UE, w gospodarstwach o różnych kierunkach produkcji. Identyfikują na bazie danych FADN, za pomocą regresji log-liniowej, różnice $\mathrm{w}$ tempie ubytku czynnika pracy $\mathrm{z}$ poszczególnych typów gospodarstw, wskazując jednocześnie, że większe było ono w nowych krajach członkowskich. Istnieje również szereg badań wykorzystujących do analizy metodę Łańcuchów Markowa (Zimmermann i in. 2009), jednakże badania te koncentrują się na danych dla jednego typu gospodarstw lub jednego kraju.

W ocenie wpływu zmian strukturalnych na produktywność zasobów szczególnie przydatna wydaje się metoda shift-share. Jest ona często stosowana do analizy zatrudnienia na poziomie gospodarki narodowej (m.in. Pender, 2003, Grodzicki, 2014), zaś na poziomie sektorowym badania dotyczą głównie przemysłu (m.in. Timmer i Szirmai, 2000, Fagerberg, 2000). W odniesieniu do sektora rolnictwa metoda stosowana była do badania wpływu zmiany struktury produkcji rolnej na jej wielkość. Wśród krajów, gdzie miała ona największe znaczenie zidentyfikowano Węgry, Bułgarię i Słowację (Tłuczak, 2016). Analizy prowadzono również dla Chin, jednak nie w odniesieniu do wydajności pracy, lecz bezwzględnej wielkości produkcji (m.in. Tang i Lin, 2010).

\section{Dane i metody}

Wykorzystane w badaniu dane Eurostat, zebrane zostały w ramach Badania Struktury Gospodarstw Rolnych (ang. Farm Structure Survey, FSS) w latach 2005 i $2013^{3}$. Dotyczą one 27 krajów Unii Europejskiej, bez Chorwacji (brak danych za 2005 rok). Ponadto w badaniu wykorzystano dane dotyczące zmian cen produktów rolnych pochodzące z badania Rachunków Ekonomicznych Rolnictwa (ang. Economic Accounts for Agriculture, EAA). W szczególności, wykorzystano zmienne:

- $\quad$ wielkość siły roboczej $\left(\mathrm{w} \mathrm{AWU}{ }^{4}\right.$ ) pośrednio i bezpośrednio ${ }^{5}$ zaangażowanej do pracy w gospodarstwie, w rozbiciu na typy specjalizacji gospodarstw (kod Eurostat: ef olfftecs);

\footnotetext{
${ }^{3}$ Korzystając z danych FSS należy pamiętać o zmianach w metodologii prowadzenia tego badania, które rzutują na wiarygodność otrzymanych wyników. Od 2010 r. zmieniono kryterium kwalifikacji najmniejszych gospodarstw do badanej próby, np. w przypadku Polski wartość graniczna wzrosła z 0,1 ha do 1 ha. Oznacza to wyłączenie z próby najsłabszych i najmniej wydajnych gospodarstw, co może skutkować zawyżeniem obserwowanych wyników przyrostu wydajności pracy (porównaj Research for... 2016, s. 93-96)

${ }^{4}$ Ze względu na duży udział zatrudnienia w niepełnym wymiarze godzin oraz sezonowego zatrudnienia pracowników dorywczych, nakłady pracy w rolnictwie zostały wyrażone w umownych rocznych jednostkach pracy (AWU). Umowna jednostka pracy (AWU) jest ekwiwalentem czasu przepracowanego w ciagu roku w gospodarstwie rolnym przez 1 osobę pełnozatrudnioną w rolnictwie. W Polsce przyjęto 2120 godzin przepracowanych w ciagu roku jako równoważnik pełnego etatu (roczną jednostkę pracy) (GUS 2015, s. 50).

W badaniu uwzględniono całkowite nakłady pracy w rolnictwie, a zatem pracę osób zaangażowanych bezpośrednio przez właścicieli gospodarstwa (również rodzinę) oraz pośrednio przez podwykonawców, spółdzielnie itp.
} 
- produkcja standardowa $\left(\mathrm{w} \mathrm{SO}^{6}\right) \mathrm{w}$ rozbiciu na typy produkcyjne gospodarstw (kod Eurostat: ef_kvftaa);

- nominalny (nie uwzględniających ogólnej zmienności cen) indeks bazowych (bez uwzględnienia subsydiów i podatków od produktów) cen produkcji, względem cen z roku 2005 (kod Eurostat: aact eaa05)

- wartość produkcji artykułów rolnych w cenach bazowych, stałych z roku 2005, w mln euro (kod Eurostat: aact_eaa03)

Pierwotne 22 grupy gospodarstw zostały zagregowane w ramach 7 typów. Jednocześnie grupa gospodarstw niesklasyfikowanych nie została uwzględniona w badaniach ze względu na brak informacji o wielkości generowanej przez nie produkcji standardowej. Jednak niewielki udzial ${ }^{7}$ tych gospodarstw $\mathrm{w}$ wykorzystaniu czynnika pracy powoduje, że ich wyłączenie nie podważa wiarygodności uzyskanych wyników. Szczegóły agregacji zawiera tabela 1 .

Tabela 1. Typy specjalizacji gospodarstw rolnych

Table 1. Types of farming

\begin{tabular}{|c|c|}
\hline Typy ogólne & Typy podstawowe \\
\hline Uprawy polowe & $\begin{array}{l}\text { Uprawy zbóż (łącznie z ryżem), roślin oleistych i wysokobiałkowych na nasiona } \\
\text { (kod Eurostat: FT15_SO), Uprawa polowa różnych gatunków roślin (FT16_SO), } \\
\text { Mieszane uprawy (FT61_SO); }\end{array}$ \\
\hline Uprawy ogrodnicze & $\begin{array}{l}\text { Uprawy ogrodnicze pod wysokimi osłonami (FT21_SO), gruntowe uprawy } \\
\text { ogrodnicze (FT22_SO), Inne uprawy ogrodnicze (FT23_SO); }\end{array}$ \\
\hline Uprawy trwałe & $\begin{array}{l}\text { Uprawa winorośli (FT35_SO), Uprawa drzew i krzewów owocowych (FT36_SO), } \\
\text { Uprawa oliwek (FT37_SO), Uprawy trwałe inne (FT38_SO); }\end{array}$ \\
\hline Krowy mleczne & Chów bydła mlecznego (FT45_SO); \\
\hline Zwierzęta trawożerne & $\begin{array}{l}\text { Chów bydła rzeźnego (FT46_SO), Chów bydła mlecznego i rzeźnego (FT47_SO), } \\
\text { Chów owiec, kóz i innych zwierząt żywionych paszami objętościowymi } \\
\text { (FT48_SO); }\end{array}$ \\
\hline \multirow{2}{*}{ Produkcja mieszana } & $\begin{array}{l}\text { Chów trzody chlewnej (FT51_SO), Chów drobiu (FT52_SO), Chów zwierząt } \\
\text { żywionych paszami treściwymi (FT53_SO); }\end{array}$ \\
\hline & $\begin{array}{l}\text { Z przewagą zwierząt żywionych paszami objętościowymi (FT73_SO), Z przewagą } \\
\text { zwierząt żywionych paszami treściwymi (FT74_SO), Uprawy polowe i zwierzęta } \\
\text { żywione paszami objętościowymi (FT83_SO), Różne uprawy i zwierzęta } \\
\text { (FT84_SO) }\end{array}$ \\
\hline
\end{tabular}

Źródło: opracowanie własne na podstawie (IERIGŻ, 2013).

Dla wyodrębnienia wpływu zmian cen na wartość produkcji w sektorze rolnym niezbędne jest wyrażenie wartości SO z roku 2013 w cenach z roku 2005. Niestety w przypadku sektorowej analizy rolnictwa przysparza to pewnych trudności. Brak bowiem wskaźników cen dla poszczególnych typów specjalizacji. Dostępne są jedynie odpowiednie indeksy dla produktów rolnych. Stąd też „urealnienia” wielkości SO dla poszczególnych

\footnotetext{
${ }^{6} \mathrm{SO}$ (ang. standard output), czyli standardowa produkcja jest to średnia z 5 lat wartości produkcji określonej działalności roślinnej lub zwierzęcej uzyskiwana $\mathrm{z} 1$ ha lub od 1 zwierzęcia w ciągu jednego roku, w przeciętnych dla danego regionu warunkach (GUS 2015, s. 46).

${ }^{7}$ W 45 na 54 przypadki nie przekraczał on 1\%, w pozostałych 7 tylko raz (dla Malty w 2005 r.) przekroczył 5\% i wynosił $9,07 \%$.
} 
typów specjalizacji dokonać można jedynie w sposób szacunkowy. Wartości SO z edycji FSS 2013 przekształcono dzieląc je przez syntetyczny indeks obliczony wg wzoru:

$$
I_{p}=\frac{\sum_{i=0}^{n} \bar{p}_{t_{1}, i} \frac{\bar{v}_{t_{1}, i}}{\sum_{i=0}^{n=} \bar{v}_{t_{1}, i}}}{\sum_{i=0}^{n} \bar{p}_{t_{0}, i} \bar{v}_{\sum_{i=0}^{n}, i}^{n} \bar{v}_{t_{0}, i}}
$$

gdzie:

$\bar{p}_{t_{0}, i}$ - średnia arytmetyczna indeksów cen z lat 2002-2006 dla i-tego produktu;

$\bar{p}_{t_{1}, i}$ - średnia arytmetyczna indeksów cen z lat 2008-2012 dla i-tego produktu;

$\bar{v}_{t_{0}, i}$ - przeciętna wartość produkcji i-tego produktu w latach 2002-2006;

$\bar{v}_{t_{1}, i}$ - przeciętna wartość produkcji i-tego produktu w latach 2008-2012.

Wykorzystanie do obliczenia wskaźników przeciętnych wartości z okresów 2002-2006 i 2008-2012 wynika z metodologii obliczeń SO. Wartości produkcji wykorzystane zostały do obliczenia wag, które odzwierciedlają udział produkcji danej grupy artykułów rolnych w całkowitej produkcji danego typu specjalizacji. Przyjęto tu upraszczające założenie, że gospodarstwa wyspecjalizowane produkują jedynie określone tą specjalizacją produkty, a także, że dany typ produktu powstaje jedynie w gospodarstwach specjalizujących się $\mathrm{w}$ tej produkcji. Do obliczenia wartości indeksów dla poszczególnych typów specjalizacji przyjęto następujące grupy produktów:

- uprawy polowe - zboża (kod Eurostat: 01000), rośliny przemysłowe (02000), rośliny pastewne (03000) i ziemniaki (05000)

- $\quad$ uprawy ogrodnicze - warzywa i produkty ogrodnicze $(04000)$

- uprawy trwałe - owoce (06000), wino (07000), oliwa z oliwek (08000)

- krowy mleczne - mleko (12100)

- zwierzęta trawożerne - bydło (11100), konie (11300), owce i kozy (11400), wełna (12910)

- zwierzęta ziarnożerne - wieprzowina (11200), drób (11500), jaja (12200)

- produkcja mieszana - ogólny indeks zmian cen produkcji rolnej (14000)

Po wstępnej obróbce danych przystapiono do dekompozycji wzrostu wydajności pracy w rolnictwie zgodnie z techniką shift-share. Istotą metody jest wyodrębnienie ze wskaźnika trzech elementów składowych informujących o wpływie różnych aspektów zmiany strukturalnej na wydajność pracy. Sformalizowany opis kolejnych etapów dekompozycji zawiera opracowanie Grodzickiego (2014, s. 139). Ostatecznie wydajność pracy opisana została w następujący sposób:

$$
g_{i, t} \equiv \frac{\Delta g_{i, t}}{g_{i, t-k}}=\underbrace{\sum_{j}\left(w_{i, j, t} \tilde{y}_{i, j, t-k} g_{i, j, t}\right)}_{W}+\underbrace{\sum_{j}\left(\tilde{y}_{i, j, t-k} \Delta w_{i, j, t}\right)}_{S}+\underbrace{\sum_{j}\left(\tilde{y}_{i, j, t-k} g_{i, j, t} \Delta w_{i, j, t}\right)}_{D}
$$

gdzie:

$g_{i, j, t}$ - stopa wydajności pracy w i-tym kraju, w j-tym typie gospodarstw, w okresie t; $w_{i, j, t}$ - udział j-tego typu gospodarstw w zatrudnieniu w i-tym kraju, w okresie t;

$\Delta w_{i, j, t}$ - zmiana udział j-tego typu gospodarstw w zatrudnieniu w i-tym kraju, w okresie t, w stosunku do okresu t-k (poprzedniego); 
$\tilde{y}_{i, j, t-k}$ - względna wydajność pracy $\mathrm{w}$ j-tym typie gospodarstw w i-tym kraju w stosunku do ogólnej wydajności pracy w i-tym kraju.

Wyszczególnione składniki sumy W, S i D posiadają interpretację ekonomiczną. Jest ona następująca:

W - średni wzrost wydajności w typach gospodarstw, przy założeniu stałej początkowej struktury zatrudnienia, ważony względnymi wydajnościami pracy. Wartość tego komponentu informuje, ile wynosiłaby stopa wzrostu przy braku zmian w strukturze zatrudnienia, a po dekompozycji sumy na składniki pozwala także ocenić rolę poszczególnych typów gospodarstw we wzroście wydajności pracy na poziomie zagregowanym;

S - przesunięcie zatrudnienia pomiędzy typami gospodarstw, skorygowane o względną wydajność pracy $\mathrm{w}$ okresie początkowym. Ten komponent mierzy efekty zmian strukturalnych w statycznym sensie - jeżeli $\mathrm{S}>0$, to gospodarka odniosła korzyści z tytułu przesunięcia pracowników do początkowo bardziej wydajnych typów gospodarstw;

D - złożenie dwóch pierwszych efektów, które informuje o dynamicznych efektach zmian w strukturze zatrudnienia. Jeżeli $\mathrm{D}>0$, to zwiększał się udział $\mathrm{w}$ zatrudnieniu typów gospodarstw o względnie wysokiej stopie wzrostu wydajności pracy. Z kolei ujemna wartość D sugeruje koncentrację pracowników w mało dynamicznych typach gospodarstw (Grodzicki, 2014, s. 140).

W kontekście badań sektora rolnego należy poczynić jeszcze jedno zastrzeżenie dotyczące interpretacji „,przesunięć” nakładów pracy. W związku z tym, że w badanym okresie wielkość nakładów pracy w rolnictwie generalnie spadała, przesunięcia należy interpretować raczej „statystycznie” niż dosłownie. Oznacza to, że nie musiały one polegać na fizycznej zmianie kierunku produkcji w gospodarstwach, lecz raczej na różnej dynamice redukcji zatrudnienia, wynikającej z postępu pracooszczędnego.

Ponadto, jak wskazuje Grodzicki (2014, s. 141) współczynnik D wrażliwy jest na długość okresu w jakim dokonywane są badania. W związku z tym, że odzwierciedla on wpływ dynamiki struktury zatrudnienia, w sytuacji gdy okres badawczy jest zbyt krótki, przyjmuje on niskie wartości, które rosną wraz z wydłużaniem okresu. Jednakże przyjęty w badaniu 9-letni okres pozwala zniwelować ten problem.

\section{Wstępna analiza danych}

W latach 2005-2013 struktura zatrudnienia w rolnictwie krajów UE uległa przeobrażeniu (rys. 1a i 1b). Zaobserwować można kierunek przemian polegający na ograniczaniu produkcji mieszanej na rzecz upraw polowych. Szczególnie w nowych krajach członkowskich UE (Litwa, Łotwa, Polska, Rumunia, Bułgaria, Węgry, Słowacja, Czechy). Stanowi to dowód postępującej w rolnictwie tych krajów specjalizacji. Jednakże również w 2013 roku udział gospodarstw prowadzących produkcję mieszaną był w tych krajach wyraźnie wyższy $(32,6 \%$, ) niż w „starych” państwach członkowskich $(8,9 \%)$. Również dla wyodrębnionych krajów CEE zmiany struktury zatrudnienia były największe. W przypadku Polski i Bułgarii polegały one głównie na spadku udziału w całkowitych zasobach siły roboczej, gospodarstw mieszanych i prowadzących chów zwierząt ziarnożernych, na rzecz gospodarstw prowadzących uprawy polowe w przypadku Polski oraz prowadzących wszystkie typy upraw w przypadku Bułgarii. Na Litwie zmniejszenie 
udziału gospodarstw mieszanych oznaczało jednoczesny wzrost udziału gospodarstw prowadzących uprawy polowe, przy niewielkich zmianach w pozostałych typach. Na Łotwie dodatkowo wzrosło znaczenie gospodarstw mlecznych i hodujących zwierzęta ziarnożerne. Podobny, choć słabszy trend zaobserwować można w Czechach. Na Węgrzech największy spadek udziału dotyczył chowu zwierząt ziarnożernych i w większości został zrekompensowany wzrostem znaczenia upraw polowych. W Rumunii z kolei spadek roli produkcji mieszanej odbił się głównie na wzroście produkcji zwierzęcej, zaś na Słowacji większy udział w zasobach pracy zyskały uprawy polowe i zwierzęta roślinożerne, kosztem zwierząt ziarnożernych i upraw mieszanych.

a)

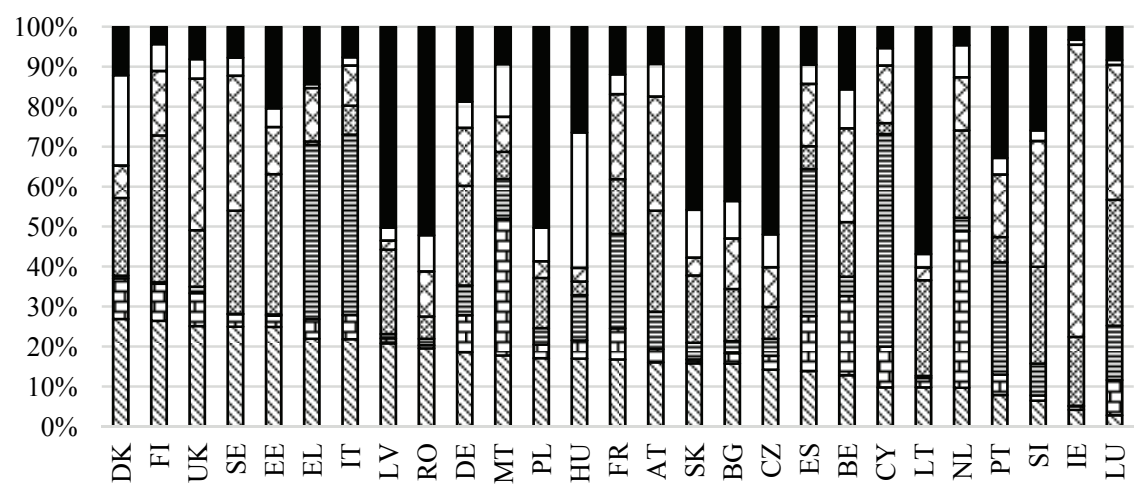

b)

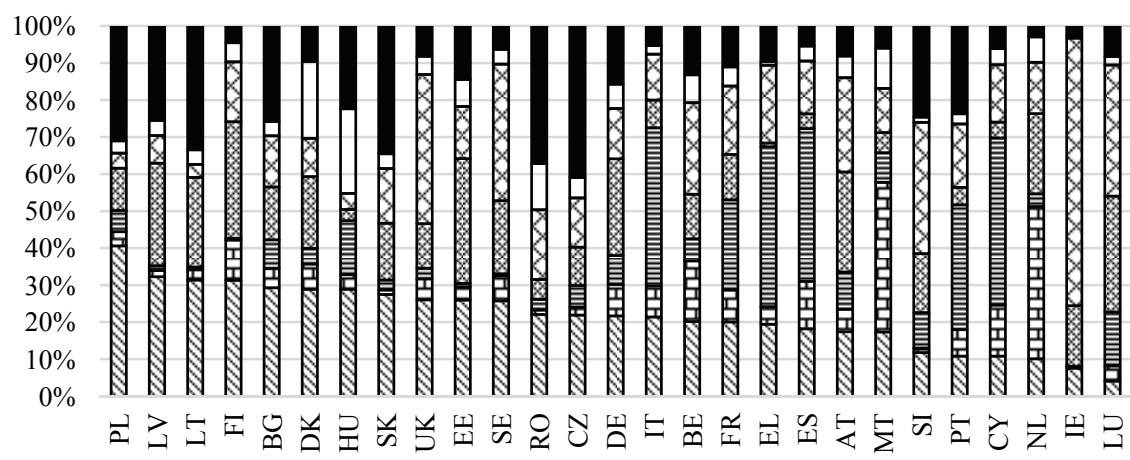
Uuprawy polowe
日Uprawy ogrodnicze
日Uprawy trwałe
rowy mleczne
曰Zwierzęta trawożerne
口Zwierzęta ziarnożerne

Rys. 1 Struktura zasobów pracy w rolnictwie państw UE w 2005 i 2013 roku w rozbiciu na typy gospodarstw Fig. 1. Structure of labor factor in the agriculture of the EU member states in years 2005 and 2013 - types of farming breakdown

Źródło: opracowanie własne na podstawie Eurostat (dostę: 01.03.2017). 
Badanie zestawia zmiany struktur czynnika pracy w rolnictwie ze zmianami wydajności pracy. W tabeli 2 zaprezentowano zróżnicowanie dynamiki wydajności pracy w gospodarstwach o poszczególnych typach produkcyjnych. Podane wielkości stanowią przeciętną wartość dla danego typu produkcyjnego w 27 krajach UE.

Tabela 2. Podstawowe informacje o 7 typach produkcyjnych gospodarstw rolnych w krajach UE-27 w latach 2005 i 2013

Table 2. Basic information about 7 types of farming in EU-27 countries in the years 2005 and 2013

\begin{tabular}{l|rrrrr}
\hline Typ produkcyjny & $\begin{array}{c}\text { Udział w } \\
\text { nakładach } \\
\text { pracy w 2005r. } \\
(\mathrm{w} \%)\end{array}$ & $\begin{array}{c}\text { Udział w } \\
\text { nakładach } \\
\text { pracy w 2013r. } \\
(\mathrm{w} \%)\end{array}$ & $\begin{array}{c}\text { Wydajność } \\
\text { pracy w 2005r. } \\
\text { (w euro } \\
\text { SO/AWU) }\end{array}$ & $\begin{array}{c}\text { Wydajność } \\
\text { pracy w 2013r. } \\
\text { (w euro } \\
\text { SO/AWU) }\end{array}$ & $\begin{array}{c}\text { Stopa wzrostu } \\
\text { wydajności } \\
\text { pracy (w \%) }\end{array}$ \\
\hline Uprawy polowe & 16,2 & 21,6 & 31207 & 42551 & 36,4 \\
Uprawy ogrodnicze & 8,1 & 8,5 & 40527 & 48784 & 20,4 \\
Uprawy trwałe & 11,9 & 12,6 & 24088 & 34825 & 44,6 \\
Krowy mleczne & 16,2 & 15,5 & 47876 & 65961 & 37,8 \\
Zwierzęta trawożerne & 17,6 & 19,6 & 20448 & 36627 & 79,1 \\
Zwierzęta ziarnożerne & 7,5 & 6,1 & 101599 & 135238 & 33,1 \\
Mieszane & 22,5 & 16,1 & 33769 & 45900 & 35,9 \\
Rolnictwo ogółem & $\mathrm{x}$ & $\mathrm{x}$ & 35001 & 48158 & 37,6 \\
\hline
\end{tabular}

Źródło: opracowanie własne na podstawie Eurostat (dostęp: 01.03.2017).

W 2005 roku w strukturze czynnika pracy w rolnictwie dominowały gospodarstwa o produkcji mieszanej, w roku 2013 uprawy polowe. Ta zmiana miała pozytywne skutki dla ogólnego wzrostu wydajności pracy w rolnictwie gdyż właśnie wśród gospodarstw prowadzących uprawy polowe był on największy. Również dynamicznie wzrastała wydajność pracy w gospodarstwach prowadzących chów zwierząt ziarnożernych, tam także wydajność pracy była najwyższa w obydwu okresach. Dlatego spadek udziału tego typu produkcyjnego w zasobach czynnika pracy trzeba uznać za niekorzystny. Najniższą dynamiką cechowała się wydajność pracy w gospodarstwach prowadzących uprawy ogrodnicze, jednak przy niskim udziale tego rodzaju produkcji nie ma to dużego znaczenia dla ogólnej stopy wzrostu wydajności pracy w rolnictwie, która kształtowała się przeciętnie dla krajów UE-27 na poziomie ok. 37\%. Oznacza to średnioroczne tempo przyrostu na poziomie 4\%. Warto odnotować również duże zróżnicowanie zarówno samej wydajności pracy, jak i jej stopy wzrostu. Praca jednej osoby pełnozatrudnionej w gospodarstwach prowadzących chów zwierząt ziarnożernych jest 5-krotnie wydajniejsza niż osoby pracującej przy chowie zwierząt trawożernych, zaś wzrost wydajności pracy w gospodarstwach prowadzących uprawy polowe był 4-krotnie wyższy niż wśród gospodarstw ogrodniczych. Zróżnicowanie to sugeruje, że wkład poszczególnych typów gospodarstw do zagregowanego wzrostu będzie zróżnicowany.

\section{Wyniki dekompozycji wzrostu wydajności pracy}

Tabela 3 zawiera wyniki dekompozycji wzrostu wydajności pracy w okresie 20052013 w krajach UE-27, która została wykonana zgodnie z równaniem (2). Wskazać można 
kraje, które najbardziej poprawiły wydajności pracy w rolnictwie. Są nimi w większości państwa CEE. Najkorzystniej w tym zestawieniu prezentuje się Słowacja, gdzie wydajność pracy poprawiła się o ponad $130 \%$. Również na Łotwie i w Bułgarii wzrosła ona o ponad $100 \%$. Wysoko w zestawieniu znajduje się również Estonia. Wspomniane kraje cechowały się w 2005 relatywnie niską wydajnością pracy, co częściowo tłumaczy wysokie przyrosty (tzw. „efekt bazy”). Nie jest to jednak reguła, że niski wyjściowy poziom wydajności gwarantuje wysokie przyrosty. Dowodem na to jest Rumunia, a w jeszcze większym stopniu Węgry, gdzie ogólna wydajność pracy w rolnictwie spadła, pomimo niskiego poziomu wyjściowego. Ogólnie oddziaływanie „efektu bazy” było niewielkie o czym świadczy niski wskaźnik korelacji przyrostu i wyjściowego poziomu wydajności pracy ($0,16)$.

Wśród krajów cechujących się wysokim przyrostem wydajności pracy dostrzec można pewne podobieństwa. Przede wszystkim przyrost ten wynikał głównie $\mathrm{z}$ postępu w poszczególnych typach gospodarstw (wskaźnik W). W szczególności wśród gospodarstw prowadzących chów zwierząt ziarnożernych, produkcję mieszaną, uprawy polowe oraz chów krów mlecznych. Jednocześnie, jako charakterystyczne dla ogółu zbiorowości wskazać można niewielkie znaczenie typów takich jak uprawy ogrodnicze, uprawy trwałe i chów zwierząt trawożernych.

Reguła ta obowiązuje z kilkoma wyjątkami. Włoch, gdzie lokalna specyfika produkcji (produkcja wina i oliwek) sprawiła, że poprawa wydajności pracy w gospodarstwach typu uprawy trwałe była jednym z „motorów wzrostu” ogólnej wydajności. Grecji, gdzie zaobserwować możemy podobne zjawisko oraz Belgii, gdzie z kolei znaczna poprawa wydajności pracy w gospodarstwach prowadzących chów zwierząt trawożernych w dużym stopniu zdeterminowała ogólną poprawę. Z kolei w przypadku Luksemburga, zdecydowana większość wzrostu wydajności pracy wygenerowana została w sektorze mleczarskim (podobnie, choć w mniejszym stopniu sytuacja wyglądała w Słowenii). W Polsce wskazać można na chów zwierząt ziarnożernych, jako kierunek produkcji, który najsilniej zdeterminowały poprawę wydajności pracy. Dostrzec można również różnice pomiędzy krajami UE-15 i nowoprzyjętymi krajami CEE. W pierwszej grupie większy przyrost wydajności pracy osiagały typy produkcyjne takie jak uprawy ogrodnicze, uprawy trwałe i zwierzęta trawożerne, w drugiej zaś uprawy polowe, krowy mleczne, zwierzęta ziarnożerne i produkcja mieszana.

Istotą przeprowadzonych badań jest jednak wskazanie jaki wpływ na wzrost wydajności pracy $\mathrm{w}$ rolnictwie miała zmiana struktury czynnika pracy $\mathrm{w}$ rolnictwie. Informują o tym wskaźniki S i D. W badanej zbiorowości zmiany strukturalne miały mniejszy udział $\mathrm{w}$ poprawie wydajności pracy niż zmiany $\mathrm{w}$ obrębie poszczególnych typów, jednak w wielu przypadkach zmniejszały one ogólny wzrost. Wskaźnik S informuje na ile zmiany w strukturze polegały na zwiększeniu wykorzystania zasobów pracy w pierwotnie (2005 r.) najwydajniejszych typach gospodarstw. Najsilniejszy pozytywny efekt wystąpił na Litwie, w Bułgarii, na Cyprze i Łotwie. W przypadku Bułgarii, Litwy i Łotwy na znaczeniu zyskiwały uprawy polowe, zaś w przypadku Cypru produkcja mleka. Również na Węgrzech, w Polsce i na Słowacji koncentracja czynnika pracy w gospodarstwach typu uprawy polowe powodowała pozytywne efekty, które jednak niwelowane były przez spadek znaczenia gospodarstw o produkcji mieszanej i chowie zwierząt ziarnożernych. 


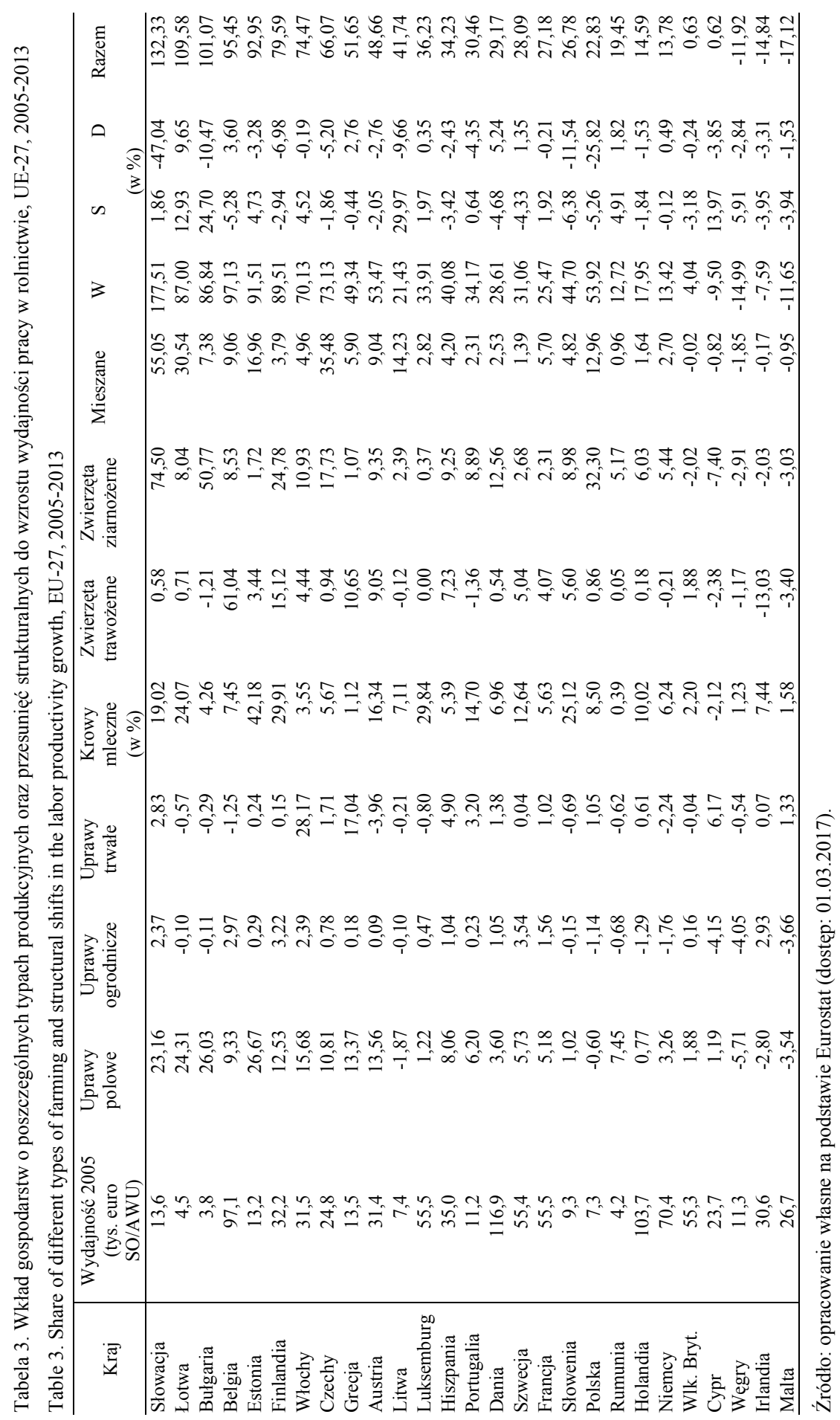


Wskaźnik D obrazuje natomiast efekty dynamiczne zmiany struktur tzn. czy zmiany zachodziły w kierunku typów produkcji o największej stopie wzrostu wydajności pracy. W tym przypadku pozytywnie wyróżniają się Łotwa i Dania, gdzie rosło znaczenie odpowiednio upraw polowych i trwałych. Częstszym przypadkiem jest jednak negatywne oddziaływanie dynamiki zmian strukturalnych na wydajność pracy. Szczególnie w krajach takich jak Słowacja, Polska, Słowenia, Bułgaria i Litwa. Na Słowacji zadecydował o tym duży spadek zatrudnienia $\mathrm{w}$ gospodarstwach hodujących zwierzęta ziarnożerne i prowadzących produkcję mieszaną. Podobne, choć mniej intensywne zmiany zachodziły w Polsce. W Słowenii decydujący okazał się spadek znaczenia hodowli krów mlecznych i zwierząt ziarnożernych, w Bułgarii zwierząt ziarnożernych, a na Litwie produkcji mieszanej i upraw polowych. Porównując ponownie kraje UE-15 i państwa CEE można zaobserwować pewną zależność. W przypadku tych pierwszych zmiany strukturalne oddziaływały zarówno $\mathrm{w}$ ujęciu statycznym i dynamicznym negatywnie, i było to oddziaływanie słabsze. Tymczasem kraje CEE dużo więcej „zyskiwały” na specjalizacji we wcześniej rozwiniętych kierunkach produkcji, jednocześnie „tracąc” ze względu na fakt, że wydajność pracy rosła w gospodarstwach tych typów mniej dynamicznie.

\section{Podsumowanie}

Wyniki przeprowadzonych badań potwierdzają wysuniętą na wstępie rozważań hipotezę, że zmiany strukturalne z dużo większą intensywnością zachodziły w „nowych” niż w „starych” krajach członkowskich, co tłumaczyć można z jednej strony potrzeba dostosowania do konkurencji na wspólnym rynku oraz wpływem wsparcia WPR, z drugiej zaś wyjściowym kształtem struktury typów produkcyjnych gospodarstw, która w tych krajach opierała się głównie na produkcji mieszanej. Kierunek zmian strukturalnych wokresie 2005-2013 w „nowych” krajach członkowskich określić można jako specjalizację, polegająca głównie na zmniejszaniu udziału zatrudnienia przy produkcji mieszanej, na rzecz gospodarstw prowadzących uprawy polowe. Wskazać można kraje takie jak Litwa, Bułgaria, Cypr i Łotwa gdzie relatywnie na znaczeniu zyskiwały typy produkcji o ponadprzeciętnej wydajności pracy. Na Łotwie i w Danii rosły udziały zatrudnienia $w$ typach gospodarstw cechujących się ponadprzeciętnym przyrostem wydajności pracy. Jednakże zmiany strukturalne raczej zmniejszały pierwotnie wysoki efekt wzrostu wydajności pracy. Wskazuje to na potrzebę prowadzenia polityki restrukturyzacji rolnictwa, polegającej na tworzeniu zachęt do specjalizacji lub przekwalifikowania gospodarstw w kierunku typu cechującego się wysoką wydajnością pracy lub wysokim potencjałem wzrostu tej wydajności. Biorąc pod uwagę fakt, że w badanym okresie zatrudnienie zmniejszało się praktycznie we wszystkich typach produkcyjnych gospodarstw, jednak z różnym natężeniem, polityka taka może polegać również na utrzymywaniu produkcji i zatrudnienia $\mathrm{w}$ gospodarstwach pożądanego typu. Możliwości takiego stymulowania zmian strukturalnych dają w perspektywie 2014-2020 narzędzia WPR, głównie poprzez płatności w ramach dobrowolnego wsparcia związanego z produkcją w I filarze oraz wsparcie inwestycji w gospodarstwach rolnych, realizowane ze środków II filaru. Kluczowe jest jednak właściwe ukierunkowanie tego wsparcia, tak by rzeczywiście stymulowało zmiany strukturalne sprzyjające poprawie ogólnej wydajności pracy $\mathrm{w}$ rolnictwie. Odpowiednich rekomendacji dostarczają badania wpływu zmian 
strukturalnych na produktywność zasobów $\mathrm{w}$ rolnictwie, prowadzone chociażby $\mathrm{z}$ wykorzystaniem metody shift-share.

\section{Literatura}

Blażejczyk-Majka, L., Kala, R. (2015). Zmiany w specjalizacji gospodarstw starych i nowych krajów członkowskich UE. Zeszyty Naukowe Szkoły Głównej Gospodarstwa Wiejskiego w Warszawie Problemy Rolnictwa Światowego, 15(2), 5-15.

Boehlje, M. (1999). Structural change in the agricultural industries: How do we measure, analyze and understand them? American Journal of Agricultural Economics 81(5), 1028-1041.

Directorate-General for Internal Policies of the Union (2016). Research for Agri Committee - Structural Change in EU Farming: How Can The Cap Support a 21st Century European Model of Agriculture? Brusselss: European Parliament, Brusselss. Pobrano z: http://www.europarl.europa.eu/RegData/etudes/STUD/2016/573428/IPOL_STU(2016)573428_EN.pdf.

Fagerberg, J. (2000). Technological progress, structural change and productivity growth: a comparative study. Structural Change and Economic Dynamics, 11(4), 393-411.

Grodzicki, M. (2014). Sektorowa dekompozycja wzrostu wydajności pracy w krajach Unii Europejskiej. Gospodarka w Praktyce i Teorii, 1(34), 35-50

GUS (2015). Rocznik Statystyczny Rolnictwa 2014. Warszawa: Zakład Wydawnictw Statystycznych.

IERiGŻ (2013), Typ rolniczy gospodarstw rolnych. Pobrane 3 marca $2017 \mathrm{z}$ https://fadn.pl/wp-content/uploads/ 2013/05/typy_rolnicze1.pdf

Kuznets, S., (1979). Growth and structural shifts. W: Galenson, W. (red.), Economic Growth and Structural Change in Taiwan. The Postwar Experience of the Republic of China (s. 15-131). London: Cornell University Press.

Leibniz Institute of Agricultural Development in Central and Eastern Europe (2007). Conceptual Framework for Analysing Structural Change in Agriculture and Rural Livelihoods, Discussion paper, 113, Halle: IAMO. Pobrano z: https://www.econstor.eu/bitstream/10419/28462/1/556634519.pdf

Peneder, M. (2003). Industrial structure and aggregate growth. Structural Change and Economic Dynamics, 14(4), 427-448.

Schmitt, G. (1990). Is Structural Change Really a Source of Economic Growth? The Case of Agriculture. Journal of Institutional and Theoretical Economics (JITE)/Zeitschrift für die gesamte Staatswissenschaft, 146(3), 470-499.

Tang, J. H., Lin, J. Y. (2010). Analysis on features of agricultural structure change and agricultural competitiveness in Hubei Province. Asian Agricultural Research, 2(5), 21-26.

Timmer, M. P., Szirmai, A. (2000). Productivity growth in Asian manufacturing: the structural bonus hypothesis examined. Structural Change and Economic Dynamics, 11(4), 371-392.

Thuczak, A. (2016). Changes in the Structure of Agricultural Production in the European Union with Particular Emphasis on Poland and Latvia. Scientific Journal Problems of World Agriculture, 16(31)/4, 301-307.

Vandermeulen, V., Mettepenningen, E., Calus, M. (2010). Sectoral mobility of production factors in agriculture and prediction for the future. Selected paper prepared for presentation at 114th EAAE seminar: Structural change in agriculture, Berlin, Germany, 15 - 16 April 2010, 1-28. Pobrano z: https://biblio.ugent.be/ publication/2004968/file/2004983.pdf

Zegar, J. (2009). Struktura polskiego rolnictwa rodzinnego pod koniec pierwszej dekady XXI wieku. Wydawnictwo Warszawa: IERiGŻ-PIB

Zimmermann, A., Heckelei, T., Domínguez, I. P. (2009). Modelling farm structural change for integrated ex-ante assessment: review of methods and determinants. Environmental Science \& Policy, 12(5), 601-618. 